\section{Research Article}

(C) 2021 Hidayah et al.. This is an open access article licensed under the Creative Commons Attribution-NonCommercial 4.o International License (https://creativecommons.org/licenses/by-nc/4.o/)

\title{
Service-learning: Learning by Doing in Community to Strengthen Students' Social Skill
}

\author{
Hani'atul Hidayah \\ Moh. Muchtarom \\ Triana Rejekiningsih \\ Department of Pancasila and Civics Education, \\ Faculty of Teacher Training and Education, \\ Universitas Sebelas Maret, Indonesia
}

DOI: https://doi.org/10.36941/ajis-2021-0082

\section{Abstract}

This research sought to find out the implementation of service-learning in senior high school. This research adopted a qualitative approach using a case study method, and it was conducted on the students of Nur Hidayah Integrated Islamic Senior High School (SMAIT NH) of Sukoharjo, Central Java, Indonesia. The subjects of this research were selected using the purposive sampling technique. The subjects consisted of the vice principal, the student organization coordinator, the dormitory coordinator, teachers, students, and the community leaders. The data collection techniques were observation, interviews, and document study. Miles and Huberman's interactive model was deployed to analyze the data. This research found that service-learning programs in SMAIT NH is an integrated education that not only emphasizes the attainment of knowledge aspect but also develops the attitudes and skills needed by students. Students directly apply learning by doing in every service-learning activity in community. Service-learning was implemented through five types of social activities including the students' real movement, fieldwork, gathering with orphans, the nation's hope generation festival, and community training. This research mainly contributes to the development of social skills by applying service-learning to the learning curriculum at school.

Keywords: service-learning, learning by doing, student, community, senior high school

\section{Introduction}

Information and communication technologies have advanced significantly in the twenty-first century. Through advancements in technology, people's lives are becoming easier where they can now access global information in real time. On the other hand, advances in global information technology have led to new social developments ( $\mathrm{Li}, 2016$; Putranta \& Kuswanto, 2018). Social changes that occur in the globalized era have transformed the noble values in society into negative personalities such as lack of respect, lack of empathy, and the tendency to be individualistic (Salam, Iskandar, Ibrahim, \& Farooq, 2019). Many young people are becoming rapidly disconnected from social relationships and social interaction, and are only concerned with making money. This increases the potential for juvenile delinquency such as student brawls, violence against parents, and a lack of concern for the existing 
conditions in the society. (Adha, 2019). Life in this globalized era requires people with a knowledge of social work, professional work in the work environment and college and the ability to use digital media to cope with social problems (Díaz, Lucena, Reche, \& Rodríguez, 2020).

In the digital age, schools play a critical role in enhancing students' social skills. Applying servicelearning to the school curriculum and engaging students to explore learning outside the classroom in various ways, which can open the boundaries of conventional classroom learning, is one way to improve students' social skills (Simsek, 2020). Students are provided with skills that benefit themselves through social service activities in the community. Service training provides students with advantages in the academic, social and emotional fields (Marcus, Atan, Talib, Latif, \& Yusof, 2019). Many previous studies have discussed the effect of service-learning on students' self-development. A study conducted by Lin et al. entitled "Effects of service-learning at a University in Taiwan" showed that service-learning is a version of intact personality education to gain academic knowledge and learn how to interact with people in society (Lin, $\mathrm{Wu}, \mathrm{Wu}, \mathrm{Pan}, \mathrm{\&}$ Liao, 2014).

There are numerous studies on service-learning. However, previous studies on university students was majorly conducted. To address this problem, service-learning has now developed in senior high school to improve students' social skill in community. From this background, this study formulates to find out the implementation of service-learning in strengthening the social skills of students at senior high school. This study enables educators and academicians to use the service learning in their learning processes and enhance students' social skills by attaining educational objectives.

\section{Literature Review}

\subsection{Service-learning}

Service-learning itself is one form of service programs developed at schools, in addition to community service and service-based internship programs (Furco, 2002). The learning aims to involve students in community service activities and relate it to academic learning in schools (Flecky \& Gitlow, 2011; Furco, 2002). This concept was first introduced to address two perceived needs of society: the need for youth and education reforms (Billig H., 200o). In addition, service-learning activities benefit students' educational excellence, as well as their social and emotional development (Marcus et al., 2019). In order to develop skills and help people in need, students can connect and use prior knowledge at school. Students become aware of existing problems, respond to them with action and actively participate in the community in each service learning activity (Karliani, 2014). This will strengthen students' personal and social skills (Furco, 2002), leading to good social skills such as cooperation, friendship, respect, and social solidarity (Alcón, 2016).

\subsection{Social Skills}

Learning in schools is not only knowledge transfer but develops certain attitudes and skills that students will require in the future, including the social skills. This is because students cannot live alone as social beings and need help from others. The main components of social development, particularly for children and adolescents, are enhancing the social skills, communicating and interacting with other people (You, Kim, \& Lee, 2017). Metiri group mentioned that interactive communication skills that include social and personal knowledge are one of the major skills in the 21st century. (Nakaya, 2018). Social skills are also one of the main skills for students to develop. They developed to facilitate interaction and benefit the group. Furthermore, social skills act as academic stimulators and support college students (Gresham, 2015). The students' social skills are described in this study as a set of positive attitudes and behaviors in social experiences such as being responsive to conditions in society, empathy, social care, communication skills, and being active in student participation and involvement in solving problems in society. 


\section{Research Method}

This study was designed with a qualitative research model which applied a case study method. It was conducted in Nur Hidayah Integrated Islamic Senior High School (hereafter as SMAIT NH) of Sukoharjo, Central Java, Indonesia. It focused on the concept, type, and implementation of servicelearning in strengthening students' social skills in senior high school. The subjects comprised of the school vice-principal, the student organization coordinator, the dormitory coordinator, teachers, students and the community. Data collection methods involved three techniques, including observation, interview and document study. It is an in-depth interview which related to the issue in this study. The observation is made by observing the service-learning process of society. This study includes a school profile, a graduate proficiency level and a service-learning accountability report. The researcher is the key instrument and the person who prepares the research instruments. The current study is underpinned by these instruments. The data validity covers data triangulation and member check. The collected data were then analyzed using an interactive model proposed by Miles and Huberman which comprises of three components including data reduction, data presentation and final conclusion and verification. (Hasanudin \& Fitrianingsih, 2020). In qualitative analysis, the researcher plays an important role in reading and rereading the data notes, focusing on what is read and analyzing the results collected during the data collecting process. The research procedure that was carried out is presented in Figure 1.

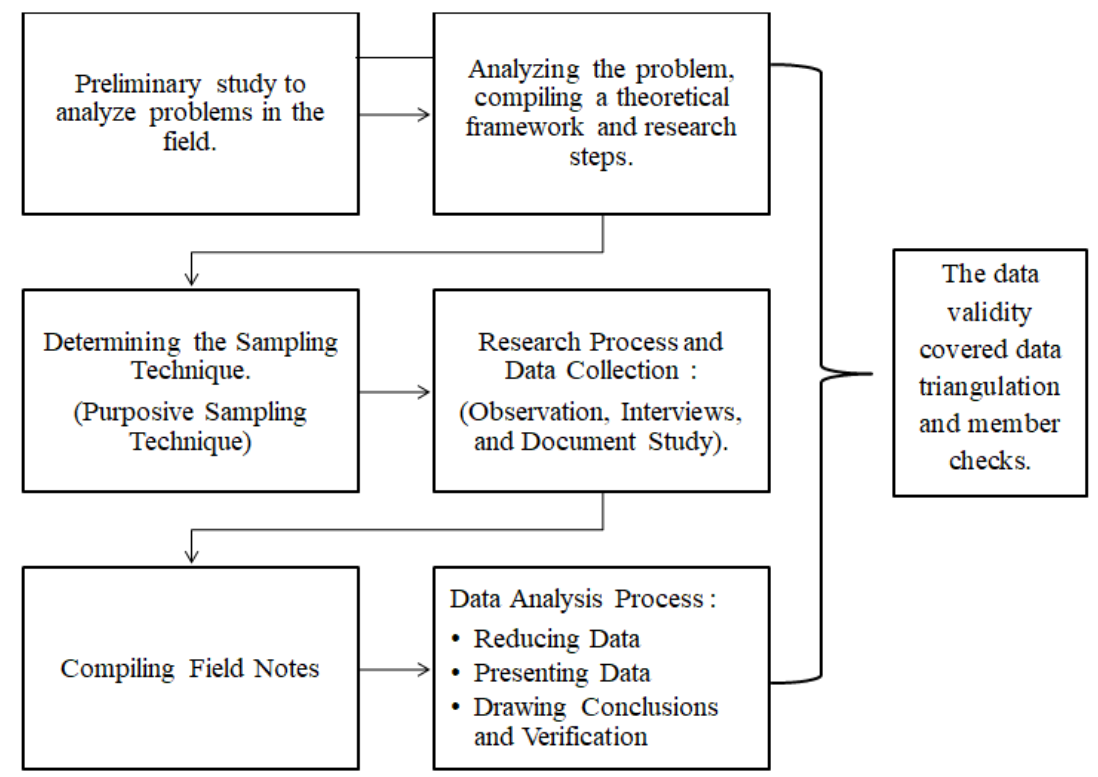

Figure 1: The research procedure

Source: Sugiyono, 2015

\section{Results}

4.1 Service-learning in Senior High School

Service-learning is one of the learning concepts applied at SMAIT NH in Sukoharjo Regency, Central Java, Indonesia. This concept is applied to strengthen students' social skills in the digital era. This learning concept developed at SMAIT NH is an integrated education that not only emphasizes the 
attainment of knowledge aspect, but also develops the attitudes and skills needed by students. This was evidenced by Informant 1 (the vice principal) stating, "These various program activities developing social skills in students are part of the graduate standards of this school and are one of the quality standards that must be achieved".

The activity was conducted to improve students' social skills, in specific including social science, civic education and religious education. The foregoing is aligned with its educational vision to become an Islamic school with environmental insights, guiding the generation to be intelligent, cultured, competitive, and caring. To achieve the above-mentioned educational objectives, a specific and measurable competency reference about the qualifications that each student must achieve is needed. Three competencies that must be achieved by students at SMAIT NH are physical competence, scientific competence, and Fanni-Jasadi competence (basic life skill). Social skills are one aspect of the Fanni-Jasadi competence the students must acquire. Starting from the above vision, competences, and standards the school must at-tain, SMAIT NH designed a set of programs that were capable of developing students' social skills in the community.

The service activities carried out covered direct and indirect events, campaigning and analyzing current issues in the community. The types of activities or programs of SMAIT NH service-learning are as follows:

Table 1: Forms of service-learning activities

\begin{tabular}{ll}
\hline Activity & Description \\
\hline Students' Real & $\begin{array}{l}\text { The activities carried out by all the students of the eleventh grade as a students' real movement } \\
\text { Movement SMAIT NH including community service, free health check and medical treatment, } \\
\text { distributing and planting trees with the community, free food distribution, cheap clothes } \\
\text { market, joint sports activities, cleaning the environment, joint religious study, and counseling } \\
\text { on the use of village natural resources. }\end{array}$ \\
\hline Field Work & $\begin{array}{l}\text { Religious social activities in the form of social service at the mosque and distribution of free } \\
\text { iftar, fun outbound and games with children, storytelling with children and Tarhib Ramadhan, } \\
\text { and teaching reading the Qur'an at the mosque. }\end{array}$ \\
\hline $\begin{array}{l}\text { Gathering with } \\
\text { Orphanages }\end{array}$ & $\begin{array}{l}\text { Student activities in the form of social service by inviting orphans to school and visiting the } \\
\text { Orphanage. }\end{array}$ \\
\hline $\begin{array}{l}\text { The nation's } \\
\text { Hope }\end{array}$ & $\begin{array}{l}\text { A festival held once a year by all the students consisting of three major activities: (1) the National } \\
\text { Generation }\end{array}$ \\
$\begin{array}{l}\text { Seminar for Youth, (2) Nur Hidayah Care, which covers activities of healthy walk, breakfast } \\
\text { Festival }\end{array}$ & $\begin{array}{l}\text { together, entertainment and giving door prize, cheap clothes bazaar, health check, and } \\
\text { training program for Indonesian young junior high school students. }\end{array}$ \\
\hline $\begin{array}{l}\text { Community } \\
\text { Training }\end{array}$ & $\begin{array}{l}\text { Dormitory activities coordinated by the caretakers with the community in the form of mutual } \\
\text { cooperation and helping social activities in the surrounding community. }\end{array}$ \\
\hline
\end{tabular}

Source: SMAIT NH archive data on service-learning program, 2019

SMAIT NH has developed a service-learning program to improve students' social skills whose metrics covered social life, religion, education and the environment. Students were directed to participate actively in any activity in the community. Students provided assistance and services to the community and learned to practice the learning they had already acquired at school. According to Informant 7 , there were a number of benefits of the service-learning program, "The service-learning program can build good communication; strengthen social skills; increase community knowledge and skills; increase student participation in community activities; and increase efforts to conserve the environment".

Teachers guided and directed students during the implementation of programs. The community participated in students' activities. Grounded in the results of interviews with students, students' perceptions of the benefits of service-learning implementation indicated that service-learning could 
strengthen their social skills. This point could be seen from students' responses to service-learning programs that they undertook. Student as informant 5 stated that, "This activity increases the sensitivity to the situation and the sense of criticism in the community". Informant 6 added, "The impact, Alhamdulillah, can change students' behavior".

Students engaged in Community Service activities alongside the community members with major impacts on the community, as shown in Figure 2.

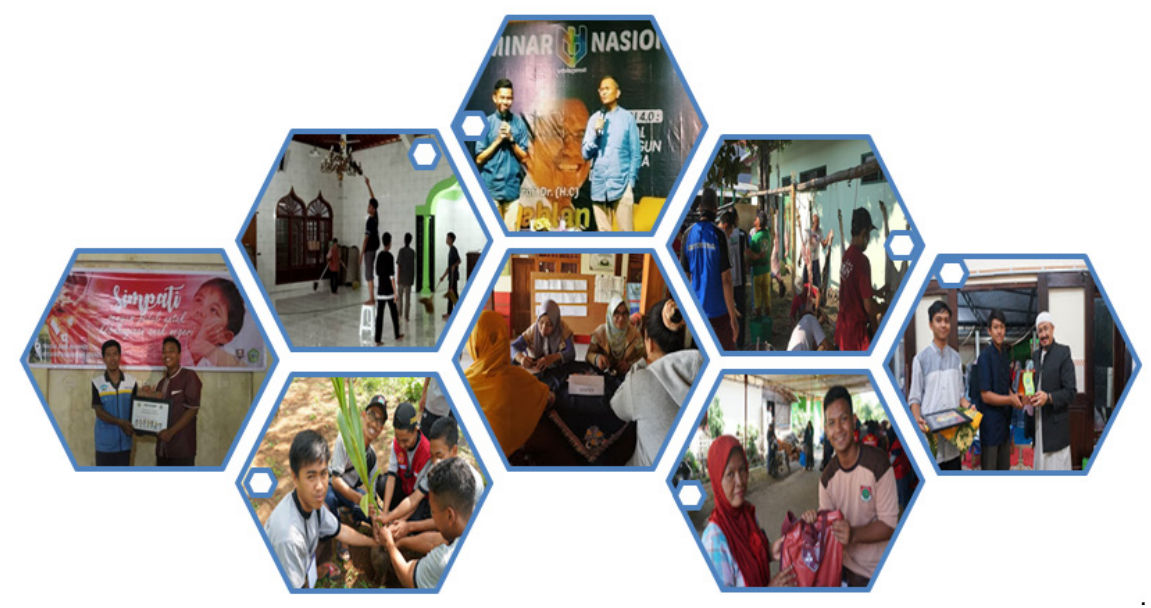

Figure 2: The activities of service-learning program in SMAIT NH

Source: SMAIT NH archive data on service-learning program, 2019

However, several barriers were discovered, although they did not discourage the implementation of service-learning activities. The following are some of the problems experienced: (1) Licensing with the village where the activities were carried out. This was because of not all villages, especially the remote villages, directly accepted activities undertaken by external parties. The community must therefore be reassured that the activities undertaken were positive. (2) The students' persistence in carrying out the seeming marathon or routine social activity such as fieldwork. This activity was carried out four times per week, so it sometimes interfered with other academic and scholarly programs or other students' activities. Therefore, scheduling was necessary so that each student could undertake his/her respective duties properly.

\section{Discussions}

In Indonesia, service learning is now reapplied at high secondary and higher education levels, including SMAIT NH in Sukoharjo Regency, Central Java, Indonesia. Service-learning is applied because it can increase students' knowledge and understanding of the community. This concept is in line with the objectives to be achieved by the Indonesian national education and also aligned with the mandate stated in article 1 paragraph (1) of Law No. 20 of 2003 concerning the national education system. Education is designed to develop academically intelligent students with a strong mentality, high spirituality, and a healthy personality. (Muchtarom, Budimansyah, \& Suryadi, 2016). The concept developed by SMAIT NH refers to integrated education, which is not simply highlighted on the knowledge aspect. SMAIT NH incorporated into the Integrated Islamic School Network (in Indonesian abbreviation known as JSIT) has an educational concept which prioritizes guidance in terms of intellectuality, spirituality, morality, and Islamic character. Besides, it is in line with the concept of education in the 21st century that must be implemented based on 4 pillars of learning processes, namely 
learning to know, learning to do, learning to live together, and learning to be (Delors, 2013).

Empirically, service-learning at this school can strengthen students' social skills in the digital era. Firstly, the implementation of service-learning has integrated learning in the family, school, and community. In line with the concept of three education centers initiated by Ki Hajar Dewantoro, education encompasses three environments which entail family, school, and community (Sasson, 2019). This approach enables students to search and then create plans to address challenges arising in schools and communities. (Farber \& Bishop, 2018). Students gain a lot of valuable experiences during the activities (Abu-Shakra \& Saliim, 2012). Service learning experience can improve the students' skills to interact and communicate with community members both directly and through online media. In line with the study's results, the service learning concept can create a significant relation between personal development and citizens' awareness (Halberstadt, Schank, Euler, \& Harms, 2019). It is easier for someone with strong social skills to speak and show his actions in the community. On the contrary, someone with poor social skills finds it difficult to interact effectively with their environment. Social skills include empathy and participation (Shea \& Bidjerano, 2012).

Secondly, the strengthening of students' social skills takes place in a social context. This corresponds to the social learning theory. The social environment is one of the important things in one's learning and thought processes. The occurring social interactions will develop more effective experiences. The more people understand things around them, the more they are able to attain certain skills, including social skills (Jjarrah, 2019). In this sense, social skills encompass one's ability to express themselves in social situations and receive community positive or negative responses (Shea \& Bidjerano, 2012). The formation of students' social skills cannot be done instantly, it takes time and needs continuous learning processes (Irmansyah, Lumintuarso, Sugiyanto, 2020). Students learn and discover new things in the social environment of the community, especially those that need help. In this social learning, students work or handle the tasks that have not been studied before but still within their reach (Putranta \& Jumadi, 2019).

Thirdly, students directly apply learning by doing in every service-learning activity. This is consistent with the idea of service-learning which was first introduced by John Dewey about "learning by doing" (Lin et al., 2014). Students learn by experiencing directly, and this makes learning valuable for them. Students learn directly from a variety of activities in the social environment, particularly in subjects such as social sciences, civic education and religious education. There seems to be knowledge about communicating with other individuals in the society in such topics (social interaction). In such a way, students can ultimately benefit others (Nafiun Lighoirihi). Students gain experiences to interact directly with the community, get to know each other, and share time, which will bring up their creativity (Alcón, 2016). These activities provide students with the opportunity to interact with the community. Most of this is essential because students are millennial generations with diverse patterns of development and rapid technological development. In addition to continuing to use technology, students' social experiences can help them develop their social skills and appreciate the conditions that exist in society. This point is supported by the explanation of Edgar Dale's Cone of Experience theory which says that learning will be effective if they immediately do something that produces certain experiences in a real sense. Any programs that meet the concept of service learning at SMAIT NH are also a form of learning that can enhance students' knowledge which is deeply implemented directly and practiced as community services. Through community service activities, students are prepared to interact with the community, as they now have different patterns of development along with rapid technological development. Students' experience in the community can improve their social skills wisely and enable them to appreciate the conditions in the community.

\section{Conclusion}

Learning emphasizes not only the aspect of knowledge but also students' attitudes and skills. A series of skills students must acquire is social skills in the community. Service-learning is one way to develop students' social skills in the community. The service-learning concept combines academic learning, 
direct services in the community to strengthen students' social skills. Service-learning of SMAIT NH is undertaken using five types of activities or programs. In each activity, students are directed to actively participate and directly be involved to improve their social skills. Social skills developed through these activities extend to finding out the conditions in the community, increasing social awareness, improving social knowledge and experiences in the community, improving the skills of communication with the community, and participating in the activities amid the community. Besides, service-learning activities also help to establish ukhuwah (relationships) between the surrounding community and school. Thus, service-learning services show benefits and positive impacts on students, the school and the surrounding community. There are various limitations to this study. First of all, this study is limited to the services-learning descriptions at SMAIT NH. Second, the study has only been performed in formal schools; it has not yet been performed in informal schools. Third, this study focused solely on the implementation of service learning in order to enhance dimensions of student social skills, not on other variables. Finally, the study on public perception of service-learning activities, the comparison of several service-learning programs in different schools and the evaluation of the service-learning programs are the existing gaps that can be further addressed by the future studies in the same area.

\section{Reference}

Abu-Shakra, A., \& Saliim, E. (2012). Including a service learning educational research project in a biology course-i: Assessing community awareness of childhood lead poisoning. European Journal of Educational Research, 1(3), 241-253. doi: 10.12973/eu-jer.1.3.241.

Adha, M. M. (2019). Advantageous of volunteerism values for Indonesian community and neighbourhoods. International Journal of Community Service Learning, 3(2), 83-87. doi: 10.23887/ijcsl.v3i2.17779.

Alcón, A. I. M. (2016). Who learns from whom? Building up intergenerational bridges through service learning. Procedia-Social and Behavioral Sciences, 228(4), 470-475. doi: 10.1016/j.sbspro.2016.07.072.

Billig H., S. (2000). Research on K-12 school-based service learning: The evidence builds. Phi Delta Kappan, 81(9), 658. Retrieved from http://search.proquest.com.proxy.library.vanderbilt.edu/openview/846fiz63bo2222577f3c9 bbd40365385/1?pq-origsite=gscholar.

Delors, J. (2013). The treasure within: Learning to know, learning to do, learning to live together and learning to be. What is the value of that treasure 15 years after its publication?. International Review of Education, 59(3), 319330. doi: 10.1007/s11159-013-9350-8.

Díaz, I. A., Lucena, F. J. H., Reche, M. D. P. C., \& Rodríguez, J. M. R. (2020). Pedagogical approaches in the knowledge society: The flipped classroom method for the development of creativity and dialogical learning. International Journal of Emerging Technologies in Learning, 15(3), 4-14. doi: 10.3991/ijet.v15io3.11664.

Farber, K., \& Bishop, P. (2018). Service learning in the middle grades: Learning by doing and caring. RMLE Online, 41(2), 1-15. doi: 10.1080/19404476.2017.141560o.

Flecky, K., \& Gitlow, L. (2011). Service Learning in Occupational Therapy Education : Philosophy and Practice. Canada: Jones and Bartlett Publishers.

Furco, A. (2002). Is Service-Learning Really Better Than Community Service? A Study of High School Service Program Outcomes. In A. Furco \& S. Billig H. (Eds.), Advances in Service Learning Research (Vol. 1, pp. 23-50). Greenwich: Information Age.

Gresham, F. (2015). Evidence-based social skills interventions for students at risk for EBD. Remedial and Special Education, 36(2), 100-104. doi: 10.1177/0741932514556183

Halberstadt, J., Schank, C., Euler, M., \& Harms, R. (2019). Learning sustainability entrepreneurship by doing: Providing a lecturer-oriented service learning framework. Sustainability, 11(5), 1217. doi: 10.3390/su11051217

Hasanudin, C., \& Fitrianingsih, A. (2020). Verbal linguistic intelligence of the first-year students of Indonesian education program: A case in reading subject. European Journal of Educational Research, 9(1), 117-128. doi: 10.12973/eu-jer.9.1.117

Irmansyah, J., Lumintuarso, R., Sugiyanto, F. X., \& Sukoco, P. (2020). Children's social skills through traditional sport games in primary schools. Jurnal Cakrawala Pendidikan, 39(1), 39-53. doi: 10.3991/ijet.v14io9.7978.

Jjarrah, H. Y. (2019). The impact of using drama in education on life skills and reflective thinking. International Journal of Emerging Technologies in Learning, 14(o9), 4-20. doi: 10.3991/ijet.v14io9.7978.

Karliani, E. (2014). Membangun civic engagement melalui model service learning untuk memperkuat karakter warga negara [Building civic engagement through service learning models to strengthen the character of citizens]. Journal of Pancasila and Citizenship Education/Jurnal Pendidikan Pancasila dan Kewarganegaraan, 27(2), 71-78. 
Li, X. (2016). Design and application of multimedia teaching video system for dance major based on cloud computing technology. International Journal of Emerging Technologies in Learning, 11(5), 68-74. doi: 10.3991/ijet.v11i11.6244.

Lin, C. Y., Wu, S. W., Wu, S. F., Pan, B. S., \& Liao, H. C. (2014). Effects of service-learning in a University in Taiwan. Procedia-Social and Behavioral Sciences, 116(4), 902-906. doi: 10.1016/j.sbspro.2014.01.317.

Marcus, V. B., Atan, N. A., Talib, R., Latif, A. A., \& Yusof, S. M. (2019). Promoting students' generic skills with the integration of e-service learning platform. International Journal of Emerging Technologies in Learning, 14(20), 4-17. doi: 10.3991/ijet.v14i20.11455.

Muchtarom, M., Budimansyah, D., \& Suryadi, A. (2016). The implementation of integrated education to develop the intact personality of students. The New Educational Review, 43(1), 147-155. doi: 10.15804/tner.2016.43.1.12.

Nakaya, A. (2018). Overcoming ethnic conflict through multicultural education: The case of West Kalimantan, Indonesia. International Journal of Multicultural Education, 20(1), 118-137. doi: 10.18251/ijme.v2oi1.1549.

Putranta, H., \& Jumadi, J. (2019). Physics teacher efforts of Islamic high school in Yogyakarta to minimize students' anxiety when facing the assessment of physics learning outcomes. Journal for the Education of Gifted Young Scientists, 7(2), 119-136. doi: 10.17478/jegys.552091.

Putranta, H., \& Kuswanto, H. (2018). Improving students' critical thinking ability using problem based learning (PBL) learning model based on PhET simulation. SAR Journal, 1(3), 77-87. doi: 10.18421/SAR13-02.

Salam, M., Iskandar, D. N. A., Ibrahim, D. H. A., \& Farooq, M. S. (2019). Service learning in higher education: A systematic literature review. Asia Pacific Education Review, 20(4), 573-593. Doi: 10.1007/s12564-019-09580-6.

Sasson, I. (2019). Building a sustainable university-community partnership: Case study in science education. Studies in Higher Education, 44(12), 2318-2332. doi: 10.1080/03075079.2018.1496410.

Shea, P., \& Bidjerano, T. (2012). Learning presence as a moderator in the community of inquiry model. Computers EEducation, 59(2), 316-326. doi: 10.1016/j.compedu.2012.01.011.

Simsek, M. R. (2020). The impact of service-learning on EFL teacher candidates' academic and personal development. European Journal of Educational Research, 9(1), 1-17. doi: 10.12973/eu-jer.9.1.1.

Sugiyono. (2015). Metode penelitian pendidikan (pendekatan kuantitatif, kualitatif, R\&D) [Educational research methods (quantitative, qualitative, R\&D approaches)]. Bandung: Alfabeta.

You, S., Kim, E., \& Lee, D. (2017). Virtually real: Exploring avatar identification in game addiction among massively multiplayer online role-playing games (MMORPG) players. Games and Culture, 12(1), 56-71. doi: $10.1177 / 1555412015581087$. 